${ }^{2}$ Sells CJ, Neff TE, B́ennett FC, Robinson NM. Mortality in infänts discharged from a neonatal intensive care unit. Am J Dis Child 1983:137:44-7.

${ }^{3}$ Chase CH. Infant mortality and weight at birth. Am J Public Health 1969;59:1618-28.

${ }^{4}$ Bendor DE, Chang C, Fisher RW, Belloc NB. Factors affecting postneonatal mortality. Health Reports 1971;86:482-6.

5 Shah FK, Abbey H. Effects of some factors on neonatal and postneonatal mortality. Milbank Mem Fund Q 1971:49:33-57.

6 Shapiro S, McCormick MC, Starficld BH, Krischer JP, Bross D. Relevance of correlates of infant deaths for significant morbidity at 1 year of age. Am J Obstet Gynecol 1980;136:363-73.

${ }^{7}$ Read A, Stanley F. Postneonatal mortality in Western Australia 1970-78. Aust Paediatr J 1983;19:18-22.

${ }^{8}$ Hack M, Merkatz IR, Jones PK, Fanaroff AA. Changing trends of neonatal and postneonatal deaths in very-low-birth-weight infants. Am J Obstet Gynecol 1980:137:797-800.

${ }^{9}$ Australia Bureau of Statistics. Causes of death. Australia. Canberra: Commonwealth Government Printer, 1982.

10 Yardley J, Wailoo MP, Harman M. Postperinatal mortality among infants discharged from special care units. $\mathrm{Br}$ Med $\mathrm{J}$ 1984:288:366-7.

1 Taylor EM, Emery JL. Two-year study of the causes of postperinatal deaths classified in terms of preventability. Arch Dis Child 1982;57:668-673.

Correspondence to Dr V Y H Yu, Queen Victoria Medical Centre, 172 Lonsdale Street, Melbourne, Victoria 3000, Australia.

Received 18 May 1984

\title{
Functional palatal incompetence in the fetal anticonvulsant syndrome
}

\author{
K N PEARL, S DICKENS, AND P LATHAM \\ Department of Paediatrics, Charing Cross Hospital Medical School, London
}

SUMmARY We report two children with mild mental retardation and appreciable articulation difficulties whose mothers took phenobarbitone and phenytoin throughout their pregnancies. The speech difficulties in both children were due to malfunction of an anatomically normal palate.

The risk of cleft lip with or without cleft palate is up to eight times greater in the children of epileptic mothers. ${ }^{1}$ We describe two children of epileptic mothers with incompetence of the soft palate leading to nasal escape and poor speech intelligibility.

\section{Case reports}

Case 1. This boy was born by emergency caesarean section at 36 weeks' gestation; he weighed $2.5 \mathrm{~kg}$. His mother, a long standing epileptic, took phenobarbitone and phenytoin throughout pregnancy. She had a single brief grand mal convulsion just before induction of anaesthesia for caesarean section. The mother also smoked heavily throughout the pregnancy, was known to abuse alcohol, and had a history of poor drug compliance. The baby seemed normal at birth and was discharged home with the mother.

He was next seen at age $3 \frac{1}{2}$ years when he presented with speech delay. History showed that the gross motor milestones had been delayed-he first sat unsupported at 18 months and walked independently at 2 years. Mild generalised hypotonia but no other neurological abnormality was found on examination. With time the hypotonia has improved and is no longer a feature. His developmental quotient on the Griffiths scales was between 70 and 80 on several occasions. His language development was delayed both in comprehension $(-2 \mathrm{SD})$ and expression $(-1 \cdot 1 \mathrm{SD})$ when assessed on the Reynell scales at 4.5 years. His speech was unintelligible because of considerable hypernasality. His height was on the third centile for his age, his weight below the third centile, and his head circumference on the 50th centile. Growth since then has continued along these parameters. He has poor dentition with deficient enamel. His vision and hearing are normal.

Investigations including electroencephalogram, electromyogram, thyroid function tests, and nerve conduction studies were normal. Examinations by an ear, nose, and throat surgeon and a plastic surgeon showed that the palate was anatomically normal with no submucous cleft; however, a cinepalatogram at age $4 \frac{1}{2}$ years confirmed abnormalities of movement of the soft palate. Normally, when swallowing or producing most speech sounds the soft palate closes against the nasopharynx. In this child the soft palate moved normally in swallowing but during speech closure was mostly inadequate allowing considerable air escape.

Case 2. This boy was born by normal vertex delivery at 38 weeks' gestation and weighed $2.75 \mathrm{~kg}$. His mother has been well with no fits during pregnancy 
or delivery and had been taking phenobarbitone and phenytoin for many years. At 2 days of age the baby was jittery and required sedation with diazepam for 48 hours. He was a slow and difficult feeder in hospital and this feeding pattern continued throughout infancy.

He presented again at age $31 / 2$ years as a slow talker. His medical history showed some delay in gross motor milestones; he had first sat unsupported at age 10 months and walked independently at two years. On examination his height was on the 10th centile, weight on the third centile, and head circumference on the 50th centile. He had pointed incisors and generally poor teeth enamel. He had a paraumbilical hernia and incurving of the fourth toes bilaterally. His vision and hearing were normal.

A Stanford-Binet assessment gave an intelligence quotient between 70 and 80 . All investigations as to the cause of his mild mental retardation and speech delay were negative. A Reynell assessment at age 5.3 years showed that his comprehension of language was delayed by $2.2 \mathrm{SD}$ and his expressive skills by more than $3 \mathrm{SD}$. A cinepalatogram at age 7 years showed normal palate structure but severe functional abnormalities similar to those described in our first patient. His soft palate rarely met the posterior pharyngeal wall at all, with gross incompetence when he swallowed or attempted to produce speech sounds.

\section{Discussion}

The first report of a higher than expected incidence of congenital abnormalities in the children of mothers with epilepsy was in $1968 .^{2}$ Since then evidence from animal studies has stengthened the view that anticonvulsants, particularly phenobarbitone and phenytoin, may be teratogenic. ${ }^{34}$ Our patients had clear histories of antenatal exposure to phenobarbitone and phenytoin. They show similar characteristics of short stature, mild hypotonia, delayed gross motor milestones, poor dentition, and mild mental retardation. Some of these features have already been described in children born to mothers taking phenobarbitone and phenytoin in pregnancy. ${ }^{56}$ Functional palatal incompetence has not been decribed previously in the fetal anticonvulsant syndrome but we believe it may be an additional variable feature.

\section{References \\ 1 Meadow R. The teratogenicity of epilepsy. Dev Med Child Neurol 1974:16:376. \\ 2 Meadow SR. Anticonvulsant drugs and congenital abnormali- ties. Lancet 1968:ii: 1296. \\ ${ }^{3}$ Mackler B, Grave R, Tippet DF, et al. Studies of the development of congenital anomalics in rats. III. Effects of inhibition of mitochondrial energy systems on embryonic development. Teratology 1975;12:291-6. \\ ${ }^{4}$ Fritz H, Muller D, Hess R. Comparative study of the teratogenicity of phenobarbitone, diphenylhydration and carba- mazepine in mice. Toxicology 1976;6:323-30. \\ 5 Seip M. Growth retardation, dysmorphic facies and minor malformation following massive exposure to phenobarbitone in utcro. Acta Paediatr Scand 1976;65:617-21. \\ ${ }^{6}$ Hanson JW, Smith DW. The fetal hydantoin syndrome. J Pediatr 1975;87:285.}

Correspondence to Dr K N Pearl, Department of Paediatrics, Charing Cross Hospital Medical School, Fulham Palace Road, London W6 8RF.

Received 14 May 1984

\title{
Subcutaneous emphysema: a new form of self abuse
}

\author{
M E McGRAW, D A PRICE, AND R J POSTLETHWAITE
}

Royal Manchester Children's Hospital

SUMMARY Subcutaneous emphysema is usually the result of trauma or surgery. We report an unusual case of a disturbed adolescent who presented with cervicofacial emphysema as a result of self abuse.

Subcutaneous emphysema may develop after tears in the gastrointestinal, genitourinary, and respiratory systems and from the entry of gas-forming organisms into the subcutaneous tissues. Cervicofa- cial emphysema has been described in association with dental procedures, the Valsalva manoeuvre, traumatic injury or surgery involving the air sinuses, and in association with pneumomediastinum. We report an unusual case of recurrent cervicofacial emphysema.

\section{Case report}

A 15 year old boy presented to the emergency department with a 12 hour history of facial swelling. 